\title{
Freedom of Religion: A Study on the Level of Understanding Among the Religious Believers in the Southern of Thailand
}

\author{
Mutsalim Khareng \\ Jaffary Awang \\ Rohanee Machae \\ National University of Malaysia, Malaysia \\ Email: habba_yabnee@hotmail.com
}

\section{Doi:10.5901/mjss.2015.v6n4s1p426}

\begin{abstract}
One of the elements of freedom is the individual freedom in embracing his or her chosen religion, as well as practicing it without any force or distraction from any party. Thailand is known as a democracy country which permits freedom to the citizens in all aspects of life including the freedom of religion. However, the interaction between Muslims and Buddhists portrays the presence of doubt among each other. This is due to the implementation of few programmes that deny the rights for freedom of religion especially among the Muslims in the Southern of Thailand. Therefore, this study will investigate on the level of understanding on the freedom of religion among Muslims and Buddhists in the Southern of Thailand. There are two approaches that are used in this study which are the qualitative and quantitative methods. Findings from the descriptive analysis have proven that the respondents did not really understand the concept of freedom of religion as most of their answers for the questionnaires given are $4.49 \%$ said they strongly disagree and $8.7 \%$ said they disagree. Nevertheless, all in all most of the respondents are strongly agreed that they have understood the concept of freedom of religion. The findings are believed to be influenced by few factors which are the roles of both Islam and Buddhism that teach the believers to be aware of the importance of freedom of religion in a community, the declaration of the freedom of religion in the National Constitution of Thailand and the Human Rights 1948 and their roles in preaching the community to acknowledge the equal rights in a community, and finally the awareness of each believer that wants to have a peaceful and harmonious life.
\end{abstract}

Keywords: Freedom, Religion, Interaction, Islam, Buddhism

\section{Introduction}

This study is an observation on the freedom of religion based on the perspective of Thailand's Constitution. In handling that right, the definition, principles and its implementation will be discussed thoroughly in investigating the level of its connection with the Theravada Buddhism which is known as the dominant religion in Thailand. The study will focus on the locations at the three districts of the Southern of Thailand which are Pattani, Yala and Narathiwat.

The position of the community in those districts is different in terms of the religion, culture and language. They are practising their respective customs and cultures by fully following their embraced religion. Even though Malays are dominating a few districts of Thailand, they are regarded as the minorities due to the political power through the cultural assimilation, national political integration and Thai education. Those factors have made them known as the Thais or the Siamese Muslims. As a result, every Thailand citizen either the resident or the immigrant, regardless of their religions should follow and respect the Laws of Thailand. That situation caused the cultural integration especially among the Muslims is always related to the religious teaching, customs, society rules and internationalism. The phenomenon has worried the Malay Muslims in defending their religion and identity as the cultural assimilation process and national political integration is directly related to the society rules that are guided by the Thailand government. Thus, it finally gave the negative impacts on the citizens especially the Malay Muslims in the Southern of Thailand (Saleh, R. 2001). The impacts can be seen through a few tragedies of fighting against the government by the citizens because of the misusing policy which led them and their religion to be the victims of betrayal.

Uniting the believers of different religions is a truly challenging effort. Misusing a policy will yield on the misunderstanding as well as conflicts between races. Hence, the effort of bringing harmony and peace to the multiracial and multi religious society requires the involvement of every citizen and believer especially the authorities. In running the 
effort, they need to be honest and highly motivated while implementing the policy to make sure that human rights are well preserved.

\section{Research Background and Problem Statement}

It is undeniable that among the content of the democracy system of a country is about the human rights (Robert, A. D. 1971). Fighting for human rights is considered as a symbol of commitment towards the democracy system in this modern world. Therefore, those who are committed to the human rights mission will be labelled as uncivilized. Thus, the issue is getting popular every second as it gets the support from the public who widely fighting for it. The issue of human rights has been a debatable issue since years and decades ago. It is similar to the issue of freedom of religion right which is under the human rights. It has been a significant debatable issue for the freedom of religion right when it comes to the argument of freedom needed by all people. This is line to the statement by Malcolm, D. E. (2004) that says freedom of religion and confidence is among the oldest and controversial right in the history of human rights.

In a democratic country, freedom of religion is among the basic policy that allows the citizens to choose and practise their religion as long as they do not interrupt the country's general right. Even though the rights have been clearly approved and announced in the National Constitution, freedom of religion is still being a debatable issue. For illustration in Indonesia, in the report of Federal Indonesian Church (including all the Protestant churches in Indonesia) and the Conference of Indonesian Church Priests (including all the Catholic churches in Indonesia) where they filed the complaint to the National Commission of the Human Rights at 14 ${ }^{\text {th }}$ December 2007 under the ruling of Susilo Bambang Yudhoyono 2004-2008. In the report, there were 108 churches including the worship houses were forcedly closed without any defence from the government. Furthermore, in other cases, the believers were also prevented from practising their religion as it was the reason for upholding the religion and country's rules because most of the Muslims have converted to Christian and committed apostasy (Ahmad Suaedy et. al. 2009).

Apart from that, in Al-Arabiya News, on the $30^{\text {th }}$ September 2013, a controversial issue has been reported where the Muslim women were prevented from wearing niqab in the public. The cases had been a debatable issue among the members of the parliament in Britain after the case of Peter Murphy, a judge ordered a woman to remove her niqab while appealing for a case at the court. The second case took place in Birmingham Metropolitan College where the students were prohibited form wearing niqab or any type of cloth to cover their face. Both of the cases had been a very hot issue until they got a wide coverage from the international media. Finally, the decision was taken back after many objections were filed against it. The other case was in a private religious school in Britain named al-Madinah which operates out of the government control. The school ordered all its women employees and teachers to sign an agreement which needed them to wear scarf regardless their religion. However, after the agreement had been widely spread to public, most of the Britain citizens launched a protest against it. The Prime Minister, Cameron, D. is also responsible in supporting the prohibition of the Muslim women to wear niqab by referring to his statement:

"We are a free country and people should be free to wear whatever clothes we like in public or in private. It's a free country and I think a free country should have free and independent institutions. When someone is coming into the country, an immigration officer needs to see someone's face. In a school, it's very difficult to teach unless you can look at your pupils in the eye." (al-Arabiya News).

Recently, on 14 $4^{\text {th }}$ February 2015, the newspaper Sinar Harian reported that the Supreme Court of Russia decided to retain the prohibition on wearing scarf (hijab) for the Muslim female students in the entire Republic of Mordovia. Based on the news agency R.T, the prohibition of wearing the scarf (hijab) has yielded the objections from the Muslims scholars and society at the district and federal levels. They stressed that the prohibition of wearing the scarf (hijab) was against the constitution of feelings and emotional freedom. Following the case, the Muslim leader of Mordovia, Fagim Shafiyev has written an appealing letter to the Russian prosecutor, to ask for the decision to be taken back. At the same time, Syeikh Ravil Gainutdin, the Head Mufti also wrote a letter to the President Vladimir Putin asking him to support the right of wearing scarf (hijab) for Muslim women in the schools or universities. Nevertheless, the government of Mordovia did not just prohibit scarf (hijab), but they also prohibited any obvious portrayal of one's religion (Sinar Harian).

The Muslim community in the Southern of Thailand which are the main focus of this study is not exempted from the issue of freedom of religion. Thailand is under the ruling of the Siamese Theravada Buddhist. The position of Theravada Buddhism in Thailand is at the highest level compared to the other religions. Therefore, the National Constitution states that the highest ruler of Thailand should be appointed from the Buddhist. Other than that, Thailand is also known as the democratic country that promotes freedom rights to the citizens in all aspects of life including freedom of religion. 
The Constitution of Thailand Section 37 states that "the right of freedom of religion is based on the right of privacy where people have the right to choose and embrace their chosen religion. Freedom of religion is the absolute freedom which means the government does not have the right to control or arrange any matters related to embracing any religion. At the same time, the practise of every religion should be based on the religious teaching which does not interrupt the public stability that could lead to misunderstanding." Besides, Section 79 states that "the government should give support and safety guarantee for the foreign religion as well as encouraging the growing of understanding among the believers.

Even though the Siamese government is putting the hard effort in giving the right to all citizens, but it is still cannot be considered as the Plural Society. The evidence can be seen in the few policies for Malay Muslims in the Southern of Thailand. From time to time, the Thailand ruler is putting various efforts to unite the Malay Muslims and the Buddhist majority. They have used various ways such as demolishing the Malay identity while growing love towards Siamese. In the other words, they try to change Malay into Siamese (which is totally different in terms of religion, culture, language, and customs) by using various ways, for instance the assimilation and integration of culture to demolish the Malay Pattani Muslim.

In the ruling policy framework, there are few policies that seem to prevent the freedom of religion among the Muslims, for example the assimilation policy of Field Marshall Phibun Songkram in 1938-1944. According to him, Thailand will not develop if the citizens are still practising different cultures among each other albeit they are living in the same country. He intended to make Thailand as a racialist country that only practises one culture with Thai way of life. In order to reach the objective, Phibun introduced the policy called Thai Ratha Niyom (Thai Cultural Declaration) in 1939. The implementation of Thai Ratha Niyom has raised worries to all citizens especially the Pattani Muslims because it will uphold the western culture and civilization as well as upholding the Buddhism policy to the entire citizens of Thailand. Hence, the identity of the minority Pattani Muslims will be threatened. In brief, in 1940 Thailand ruler had formed spha wathana'tham (Cultural Policy) to ensure the Thai Rathaniyom policy was succeeded (Ibrahim, S. 2005).

The Thai Ratha Niyom policy is in fact marks the earliest interruption of Thailand in the Islamic matters as the Islamic Laws that had been practiced before had been demolished by Phibun and replaced with the Civil Laws. Phibun had declared a fight for any effort towards the Islamic development. The Buddhism idols were placed at all schools and the pupils were forced to worship the idols together with the Buddhist pupils. Other than that, the Malays who worked as the civil servants were forced to change their names to Siamese language and they were not allowed to hold any higher position. They had to learn how to speak Siamese language, and they were not allowed to speak Malay in any business at the government offices. In addition, they were also not allowed to learn Al-Quran, but they were encouraged to learn Buddhism. Besides, the Malays were also forced to wear pants and hats, while the Muslim women were not allowed to wear scarf (hijab) (Achwanichakun, K. et. al. 2009). The forceful implementation of policies by Phibul had hurt the feelings of the Malay Muslims which caused most of them to be arrested and jailed if they did not want to follow those policies or supporting any Pattani freedom movement (Nik Anuar, N. M. 2006).

Nonetheless, in 1945-1946, the government under Pridi Phanomyong was putting the effort to defend the Malay Pattani Muslims rights by changing the cultural assimilation policy led by Field Marshall Phibun Songkram to the peaceful policy towards the national political integration. The implementation of this new policy was directly allowed the opportunity to practise the Islamic rules; helping and supporting the Islamic matters, introducing Chularajmontri (The Highest Islamic Board in Thailand), introducing the committee of religious matters, forming the Islamic education institution, and allowing the learning of religion by using Malay and Arabic languages (Pissuwan, S. 1982). The opportunity given was under the declaration of Islamic Act 1945 which aimed to break the barriers among the Siamese ruling and the Muslims. The introduction of that act has clearly stated that:

"Since the Siamese constitution gives freedom of religion to the citizens as the king being the main religious protector, therefore, it is relevant for some of the Siamese to embrace Islam and get assistance and protection in their religious matters" (Nik Anuar, N. M. (2006).

Even though various offers are given by the government to the Malays, they are still not satisfied with them as that portrays the government is still holding the power in determining the Muslim scholars roles in every religious matters as well as trying to mix the Buddhism with Islam. Furthermore, the bad experience of Malays during the reign of Field Marshall Phibun Songkram is impossible to be forgotten.

The bad experience of the Malay Pattanis did not meet the end line. In the beginning of 1970, the Islamic preaching programme known as thamacarit (the dharma immigrant) which started by the Ministry of Home Affairs distributed the fake writing of Al-Quran to the Malay Muslims. Even though the Thamacarit officer defended that activity by saying that it was an unrealized mistake, Muslims knew that it was their effort to the demolish the Malay Muslims 
especially in the four districts of the Southern of Thailand. Other than that, in 1980, the Ministry of Education spread a religious text consisting the drawing of Prophet Muhammad (P.B.U.H) photo. According to the Islamic teaching, the portrayal of Prophet Muhammad (P.B.U.H) in any image is clearly prohibited. The actions should not take place whether with or without intention among the community who have the strong faith of Islam (Wan Kadir, C. M. 1998).

In 1988, the Deputy Governor of Narathiwat, Somphong Sriyaphan had worsen the situation by making the controversial statement that criticized and humiliated some of the Islamic teachings including the issue of wearing scarf (hijab) among the Muslim women. According to him, most of the Muslim women in the Southern of Thailand did not have the right to make decision as they were just being the play tools for the men and the religious pressure was also too much on them (Jidmoud, S. 1988). Finally, he had been asked to quit the position because of humiliating Islam.

At the same year of 1988 , there was a major demonstration by the female university students on the issue of wearing scarf (hijab) in Yala Rajabhat University. The controversial demonstration took place when a group of Muslim female students appealed to the university to give them permission to wear scarf (hijab) in the classroom, but the request was rejected. Following the rejection, the Muslim female university students decided on having the major demonstration including the male students, academicians and the public from all over the places. As a result, the university gave permission for the female students to wear scarf (hijab), (Panjor. R. 2012).

The issue of wearing scarf (hijab) was again becoming the alarming issue in 2011. During that significant year, a Muslim girl who studied at the secondary level in Sekolah Menengah Kerajaan Vad Nongcok (Bangkok) had applied to wear scarf (hijab) during her school time, but it was rejected. After that, on $1^{\text {st }}$ December 2011, the committee of Sekolah Menengah Kebangsaan Vad Nongcok had officially announced that wearing scarf (hijab) is not permitted in the school area either the students or the staff as it violated the school's rule, the ministry of education's rule and the school's cultural rule that had been set, even though the area involved was lived by the Muslim majority of $75 \%$ compared to the Buddhists which were only $20 \%$ of them.

It is impossible to deny that a multi religious and multiracial society will experience the misunderstanding or crisis either from the behaviour or the action. The crisis is known as Prejudice and Discrimination on a certain race or making an individual to become obsessed with his or her religion. The behaviour can be identified among the races who strongly dominated the other races because of the different religious, customs and cultural practices. That behaviour is a cultural nature that can occur in any society which has different religions or races (Alisa, H. 2009). Moreover, Ali, D. (2012), claimed that the highest policy of Thailand is about providing the freedom of religion and the right to practise it to the believers. Nevertheless, the society is still being prejudice especially among the Buddhist towards the wearing of scarf (hijab) by the Muslim women. They did not accept the fact that the laws have given the permission for wearing scarf (hijab) by finding the arguments to prove that wearing scarf (hijab) is not proper in the society of Muslim minority.

Consequently, even though the freedom of religion is clearly stated in the Constitution of Thailand, the majority believers of Buddhism did not acknowledge the rules and regulations. This is because, they view the traditional way of life and customs as the main benchmark of rules and regulations compared to the written constitution. As a result, the doubts occurred towards the practices of other distinguish religions and customs.

\section{Methodology}

The study used the qualitative and the quantitative method. The qualitative method means that the variable can be concluded in the form of non-numeric. However, the quantitative method allows the variable to be concluded in the numeric form. The combination methods are used to strengthen the findings (Creswell, J.W. 1994). This combination approach can be referred to the writing of Frechtling, S. \& Westat (1992), which stated that:

"Combining the two methods pays off in improved instrumentation for all data collection approaches and in sharpening the evaluator's understanding of findings".

The use of qualitative approach can assist the researcher to collect and get more comprehensive data and information on the researched issue. The use of quantitative method alone is not essential to evaluate, explain and discuss the personality of a respondent. Fink (1995) declared that the observation method is a system to collect data to explain, compare or explain the knowledge, attitude and behaviour. The statement supports the choosing of observation methods used in this study which are explaining, combining and relating between the level of understanding on freedom of religion and the open-minded attitude of both society towards the other religions believers. Besides, the factors influence the level of understanding are also associated to the open-minded attitude of the society towards the other religions believers. 


\subsection{Sample of the Study}

The samples used in this study are the residents who live in the city of Yala, Pattani, and Narathiwat. The distributions of the residents are as follow:

Table 1.1 Statistics of the Buddhists and Muslims in the 3 districts of the Southern of Thailand which are Yala, Pattani, and Narathiwat.

\begin{tabular}{lccccc}
\hline District & \multicolumn{3}{c}{ Population of residents } & \multicolumn{2}{c}{ Population of believers } \\
\hline Bandar Pattani & male & female & total & Muslims & Buddhists \\
Bandar Yala & 52,728 & 70,279 & 123,007 & 108,368 & 14,639 \\
Bandar Narathiwat & 24,064 & 28,431 & 52,495 & 23,222 & 29,121 \\
\hline
\end{tabular}

Source: Yala Regional Hospital 2012

Based on the statistics above, the population distribution is not balanced. The majority residents of Pattani are Muslims while the majority residents of Yala are Buddhists and the rests are the residents of Narathiwat. However, generally, the population of Muslims and Buddhists are equitable. Thus, the researcher will investigate on the respective districts. Firstly, the researcher will observe the potential research locations to ensure that the samples chosen are reliable in giving the data for this study. The process of choosing the population and sample will be based on the table structured by Krejcie \& Morgan (1970) which used stratified sampling procedure. Hence, the research population for this study by following the primed conditions resulted in 380 people per area.

\subsection{Instrument}

There are three field research instruments used in this study which are the questionnaires, interview and direct observation. Those instruments were chosen as they are the among the easy instrument forms that can be used in getting the information from the respondents. The questionnaires were distributed as one of the planned procedures to determine the respondents' attitude, interest, demographic and other details related to one or more variables (Wiseman, D. C. 1999). Other than that, the structured interview method was also used in this study. The target respondents were from various characteristics such as the general worker, religious officers, and local academicians. The interview was conducted to get more detailed information on the level of understanding towards the freedom of religion which relates to the National Constitution of Thailand declaration as well as asking for detailed explanation on certain issues. By using that method, the understanding on certain studied aspects can be strengthened by the process of triangulation (Cohen, $\mathrm{L}$. Manion, L. Morrison, K. 2000). Additionally, the field research direct observation was the most suitable method to investigate on the real details of certain issues. Based on the observation, the researcher can analyse the subject's behaviour based on the identified variables. The researcher will observe the changes in behaviour, listen and look at the subject's behaviour from any distance. In using this method, the researcher or the observer needs to observe the samples for a certain period. The observation method is suitable especially when the researcher wants to investigate on the development of behaviour of a social unit. Before the observation takes place, the researcher needs to have a proper and thorough planning. Besides, every observation should have the specific objectives that are conducted systematically, complied with high level of focus and perfectly written notes. The written notes should be accurate, verified and reliable. Observation involves the acts of observing, taking notes and recording event and behaviour for a specific studied field. Even though the researcher follows the subject's behaviour, the researcher cannot influence him or her for a specific behaviour. By following that rule, the researcher will have a true perception on the collected information (Mohd Majid, K.. 1994).

\subsection{Data Analysis}

The descriptive analysis method is used to investigate the level of understanding on freedom of religion among the religious believers in the Southern of Thailand. The data will be analyzed by looking at the mean, mode, percentage and standard deviation. Apart from that, the statistics obtained consists of the subject's profile; age, level of education, gender, marital status, religion, friends of different religion, residential area and working status as a whole. The data were 
interpreted descriptively by using the mean scale table which each dimension has been arranged descending from the highest mean to the lowest mean. Besides, the standard deviation was also interpreted to get the average difference of scores in the data tabulation. Thus, the low to average value of standard deviation shows that there is a little mean difference from that mean tabulation.

The low standard deviation value on the item shows that the respondents have given high consensus responses. In contrast, if the value of standard deviation is high to the highest, that means the consensus responses from the respondents are low.

\section{Results}

The findings were analyzed descriptively to investigate on the level of understanding among the respondents on the freedom of religion. The researcher has constructed the items based on the definition of freedom of religion, freedom of religion among the non-Muslims, freedom of religion among the Muslims, freedom of religion is not allowed to violate the other people's rights and the importance of freedom of religion. In brief, the mean score analysis on the level of understanding is shown in the table below;

Table 5.1 Mean and Sd tabulation of understanding on freedom of religion

\begin{tabular}{|c|c|c|c|}
\hline $\mathrm{Bil}$ & Item & Mean\&Sd & Int \\
\hline B13 & Freedom of religion is people have the right to choose and embrace their chosen religion. & $4.06 / 0.90$ & High \\
\hline B14 & Freedom of religion is people have the right to practise their religion. & $4.20 / 0.87$ & High \\
\hline B15 & Freedom of religion is people have the right without any force. & $4.21 / 0.85$ & High \\
\hline B16 & Freedom of religion is can't force someone to profess a religion. & $4.00 / 0.96$ & High \\
\hline B17 & Freedom of religion is natural rights that each person. & $4.09 / 0.93$ & High \\
\hline B18 & Non-Muslim have the right to follow any religion. & $3.93 / 1.02$ & High \\
\hline B19 & Non-Muslim have the right to convert the religion. & $4.01 / 0.98$ & High \\
\hline B20 & Non-Muslim have the right to become an atheist. & $3.19 / 1.25$ & Average \\
\hline B21 & Muslims can't convert the religion. & $3.20 / 1.44$ & Average \\
\hline B22 & Muslims can't to become an atheist. & $3.14 / 1.46$ & Average \\
\hline B23 & $\begin{array}{l}\text { The practise of every religion should be based on the religious teaching which does not interrupt } \\
\text { the public stability that could lead to misunderstanding. }\end{array}$ & $3.66 / 1.00$ & High \\
\hline B24 & In freedom of religion has certain limitation in the public interest. & $3.45 / 1.08$ & Average \\
\hline B25 & $\begin{array}{l}\text { Freedom of religion should be guided by the rules of religious law in the country in order not to } \\
\text { affect the rights of other faiths. }\end{array}$ & $3.94 / 0.95$ & High \\
\hline B26 & Violations of religious freedom could spark conflict in society & $3.78 / 0.93$ & High \\
\hline B27 & Freedom of religion rights can establish unity among religions. & $3.81 / 0.91$ & High \\
\hline B28 & The basic freedom of religion play an important role to the unite religions. & $3.79 / 0.89$ & High \\
\hline B29 & Freedom of religion as a Technique of Resolving Religious Conflict & $3.73 / 0.93$ & High \\
\hline B30 & Act 37 about freedom of religion in the Constitution of Thailand important to the unite religions. & $3.63 / 0.98$ & High \\
\hline & Total Mean & $3.77 / 0.54$ & \\
\hline
\end{tabular}

\section{Source: Researcher}

Table 5.1 shows 18 items on the level of understanding on the freedom of religion among the residents of the three districts of the Southern of Thailand (Pattani, Yala and Narathiwat). There are 14 items that score the high mean which are 3 items on the freedom of religion in embracing, practising and spreading the religion at items B13, B14 and B15 with recorded mean score and standard deviation (mean=4.06/ $\mathrm{sd}=0.98$, mean=4.20/ $\mathrm{sd}=0.87$ and mean $4.21 / \mathrm{sd}=0.85$ ). There are 2 items about no coercion in embracing the religion at B16 and B17 with the obtained mean score and standard deviation (mean=4.00/ $\mathrm{sd}=0.96$ and mean=4.09/ $\mathrm{sd}=0.93$ ). The 2 items on the freedom of religion among the non-Muslims at B18 and B19 with the mean and standard deviation score (mean=3.93/ sd=1.02 and mean=4.01/ $\mathrm{sp}=0.98$ ). The next 3 items are on freedom of religion is not allowed to violate other people's rights at B23, B25 and B26 with the obtained mean and standard deviation score (mean=3.66/ $\mathrm{sd}=1.00$, mean=3.94/ $\mathrm{sd}=0.95$ and mean=3.78/ $\mathrm{sd}=0.93)$. The other 4 items are on the importance of freedom of religion at B27, B28, B29 and B30 with the mean and standard deviation score (mean $=3.81 / \mathrm{sd}=0.91$, mean $=3.79 / \mathrm{sd}=0.89$, mean $=3.73 / 0.93$ and mean $=3.63 / \mathrm{sd}=0.98$ ). 
The next 4 items obtained the average level of mean score which is one on the freedom of religion among the nonMuslims at B20 with the mean and standard deviation score (mean=3.19/ sd=1.25). Next, 2 items on freedom of religion among the Muslims at B21 and B22 with the mean and standard deviation score (mean=3.20/ sd=1.44 and mean=3.14/ $\mathrm{sd}=1.46$ ). There is 1 item on freedom of religion is not allowed to violate other people's right at B24 with the mean and standard deviation score (mean $=3.45 / \mathrm{sd}=1.08$ ).

In summary, the average percentage of responses towards the questions related to level of understanding on freedom of religion is shown in Figure 5.1 below;

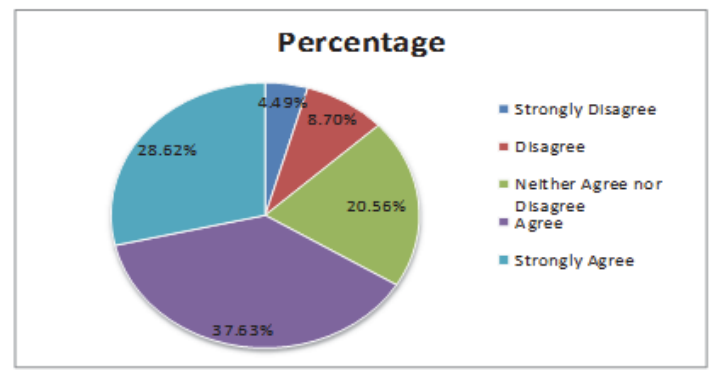

Rajah 5.1 The average percentage of responses towards the questions related to level of understanding on freedom of religion (Source: Researcher)

\section{Discussion}

The discussion is based on the findings from the descriptive analysis on the level of understanding on the freedom of religion among the Muslims and Buddhists in the Southern of Thailand. The findings prove that the respondents do not really understand the freedom of religion accurately because the responses towards the questions given recorded that $4.49 \%$ of them strongly disagree and $8.7 \%$ disagree. In contrast, if the findings are viewed as a whole, the respondents are having good understanding on the freedom of religion.

The findings might be influenced by a few factors such as the role of religion (Islam and Buddhism) which taught the believers to be aware of the significance of freedom of religion in living as a community, the declaration of freedom of religion in the National Constitution of Thailand and the Human Rights 1948. The other roles are in forming the community which agreed on the equal rights in a community and the awareness of every believer who wished to live in peace and harmony. The detailed discussions are as follow.

Based on the researcher's observation, the religious teaching (Islam and Buddhism), are coming from different the sources and authorities. The acknowledgement of freedom of religion in Islam is based on Al-Quran. As the words of Allah in surah al-Baqarah verse 17 and 256, surah Yunus verse 99, surah al-Maidah verse 104, surah al-Kafirun verse 6 and surah al-Mumtahinah verse 8-9. Whereas the acknowledgement of freedom of religion in Buddhism is by referring to the teaching of Buddha to Tripitaka in the lesson of Kalamasuttra that comprise of; a) Ma Anusasawen, do not merely believe on the repeated history, b) Ma Paramuprai, do not believe just because it is tradition, c) Ma Itikirai, do not believe on rumours, ) Ma Pithoksamupathanen, do not believe just because it is in the book, e) Ma Takukahettu, do not believe just because it is logical, f) Ma Nayahettu, do not believe just based on reasoning, g) Ma Akorpariwitkuken, do not believe just because it is similar to your thought, h) Ma Thitthinichamanokkukhanuthitaya, do not believe just because the theory has been decided, i) $\mathrm{Ma}$ Phapuphrutai, do not beleive just because a person looks capable on something, j) $\mathrm{Ma}$ Sammanornokhruti, do not believe just because someone said that "He is our respected teacher"

Based on the principles discussed by the researcher in the earlier section on measuring the barrier of freedom of religion, it is obviously identified that there is a difference of it in Islam and Buddhism. In Buddhism, freedom is given to the believer to convert the religion or become an atheist after they have embraced Buddhism. This right nails the Civil Law that is quite similar to almost all non-Muslim countries including Thailand. It can be deniable that the formation of the National Constitution of Thailand is influenced by Buddhism. The teaching of Kalamasuttra on the freedom of religion is also included, as Thailand is founded by Theravada Buddhism that yields on the majority of citizens are among the Buddhists. In that case, the position of Budhhism is higher than other religions. Holland agreed on this process as he stated that the resource and influence of forming a democratic country's laws are based on the religious teaching, 
customs, scientific discussion, judgement and punishment, laws, belief of a race, agreement, government news, laws commentary and laws restructuring (Ahmad Redzuwan, M. Y. 2001).

Other than those sources, the formation of laws is also based on the fact that Thailand is one of the members of the United Nations which subjected to the international laws norms written in the United Nations Charter and the Declaration of Human Rights 1948. Therefore, the basic principles in measuring the barrier of freedom of religion are directly related to the declaration of freedom of religion in the Declaration of Human Rights 1948. The relationship can be seen from the freedom of religion authority in the National Constitution of Thailand which sticks on the constitution that is based on the human thinking in evaluating an issue. Hence, all believers are viewed equally in the National Constitution of Thailand. Freedom of religion is a part of the essential rights in promising that those rights will be permanently meaningful until they are legally put under the constitution of most civilized and monarch countries, including the countries under the United Nations (Declaration of Human Rights).

In short, both laws acknowledge, respect and allow the citizens to have freedom of religion by giving them rights to choose, embrace, practise, spread the embraced religion, convert the religion, or become an atheist.

Nevertheless, Islam does not allow the believers to convert the religion or become an atheist after they have embraced Islam as the act can be punished. Converting from Islam to other religion is regarded as apostasy or it is called as the act of betrayal. Since Muslims in Thailand are the minorities, it is impossible to have the act of converting from Islam to other religion or becoming an atheist as a crime that can be put on trial at the Syari'e Court or the Civil Court.

Despite all the differences, both religions are sharing the same perspective on the freedom of religion which are the freedom to embrace, practise, spread, no coercion in religion, the freedom of religion is not allowed to violate other people's religion, and acknowledging that freedom of religion as a right that should be enjoyed by everybody. Both religions are running the effort in forming the harmonious environment and stressing on the humanity by putting the collective significance as the main benchmark when talking about the right of freedom of religion. Thus, everybody has the right of freedom of religion, but they are not allowed to simply violate the other people's rights or the public safety. In addition, the right needs to be complemented with the consensus agreement to ensure that it does not violate the others' rights and benefits.

In the other words, if the practice or spreading of a religion found to be an interruption of the public safety, it could be blocked or legal action could be taken as to preserve the public safety. This means, the right of freedom of religion which is acknowledged by the national laws and the Declaration of Human Rights 1948 which is based on the human thinking and it has been the theory in prioritizing the collective rights compared to the individual rights for the sake of public welfare and peace. Even though this foreign philosophy is only based on the laws and essential rights, it possesses the similar objective with Islam which is on the different levels of collective right to individual right.

The declaration of freedom of religion in the National Constitution of Thailand and its relationship with the announcement of the Declaration of Human Rights 1948 play the significant role in forming a community that accept and respect the right of freedom of religion as it portrays the high level of understanding on freedom of religion among the residents of the three districts of the Southern of Thailand. The statement is relevant as the chosen respondents are among those who graduated and work in the government or private offices. That supports the reliable experience and educational level of the respondents in mingling with the other religions' believers. Thus, it can be understood that the process of understanding the freedom of religion concept has started since their school or teenage years. Najeemah (2005) remarks, educational institutions are the most appropriate places to educate people on the concept of social interaction spirit. This is because, those places are the basic step in integrating the students who came from various ethnics and learn in the same tolerance culture. The educational institutions are not just the places to provide knowledge and skills, but they are also functioning as the adaptation places, tolerance and good moral values. Furthermore, Abu 'Urwah (2001) supports that opinion by stressing that educational institutions are greatly affecting the human lives. Education is a process in familiarizing the soul with the aimed objectives of the educational ambitions. The statement is further supported by Jaffary et. al. (2007) where he stresses that the roles of educational institution are very important in forming an individual identity. That means, if the policies have been imposed into an educational process such as the tolerance objective, it can create the value of cooperation and loving towards each other in a community. Nevertheless, if the policies such as prejudice and discrimination are introduced, the community created will be filled with misunderstandings and fights among the believers.

The findings of this research is similar to the findings of the research by Tonsungnern, S. (2010) which studied on the right of freedom, indicate that majority of the residents in the city of Anusawari, Bang Khen, Bangkok have the high level of understanding on the freedom of embracing any religion based on one's belief without any coercion, followed by the freedom in giving opinion, giving speech, writing and propagating. He further indicates that the level is high as the majority of the residents from (the city of Anusawari, Bang Khen, Bangkok) are aware that they want to live freely in all 
aspects either the personal, society and country's necessities. Presently, even though almost all the rights are verified and written in the National Constitution of Thailand edited in 2007, part 3, Section 26-69 on the right and freedom among the Thailand citizens, there are still part of minorities who do not receive their rights in medicine, education, occupation, land property, fair competition, demonstration and other rights. The issue caused by a few factors which are the high level of selfishness, the misusing of power among the government main officers and the absence of good moral value in a community. That portrays the citizens do not really possess the ultimate right under the democracy ruling which opposites the society conceptual in the democracy system which is also understood as the nationalism; the benefits and wishes of the citizens should be the only source in making any decision.

The confession of the right of freedom especially the freedom of religion in the context of multi religious country is among the vital step in facing the religious conflicts and forming the cooperative community in a democratic way. This is because, according to al-Qasimi (2004), religion is the ultimate guiding tool for human which consists of various functions. Religion is also the best guarantee in forming the human relationship under the fair principles of a community life. Hence, the corruption of religion will result in the corruption of a civilization too. Other than that, religion plays a vital role in combining the hearts of believers by using a love thread and solidarity which cannot be fought by other elements such as race, language, neighbourhood or other benefits (Sulaiman, I. 2003). Consequently, the freedom of religion should be nicely practised, filled with motivation and honesty to avoid from people who practise the wrong teaching to claim for the freedom of religion.

\section{Conclusion}

The descriptive findings on level of understanding on the freedom of religion among the religious believers as a whole can be concluded to be at a good level. This proves that the majority of the religious believers understand the definition, principles and the significance of freedom of religion when living in a community. The findings are influenced by the religious teaching on the peaceful facts brought by the religion to the believers. Besides, the declaration of freedom of religion and the National Constitution of Thailand and the Human Rights 1948 also play the vital role in forming the community to acknowledge the equal rights in living as a community and finally the awareness among the religious believers who intended to live in peace and harmony.

\section{References}

Abu 'Urwah. (2001). Islamic Systems: Analysis Comparative. Kuala Lumpur: Pustaka Salam sdn. Bhd.

Achwanichakun, K. et. al. (2009). Violence and death under government policy: case studies of three regions South Thailand. Bangkok: Prayathai.

Ahmad, R. M. Y. (2001). Demokrasi dan Kepimpinan Islam Suatu Perbandingan. Kuala Lumpur: Percetakan Cergas (M) Sdn. Bhd.

Ahmad, S. et. al. (2009). Islam, Constitutional and Human Right: Problems of Freedon of Religion and Belief in Indonesia. South Jakarta: The Wahid Institute.

Al-Arabiya News. 30 September 2013. Cameron Expresses Support for Muslim veil ban in UK Schools. (http://english.alarabiya.net/en/ News/world/2013/09/30/Cameron-expresses-support-for-Muslim-veil-ban-in-schools-html) [16 February 2015].

Ali, D. (2012). http://www.law.cmu.ac.th/law2011/177404/indez.php [6/April/2013].

Alisa, H. (2009). Muslim identity in Rueso Komunity: Southernmost Province of Thailand. Academic Journal Faculty of Humanities and Social Science.Prince of Songkhla University Pattani Campus.

Al-Qasimi, M. (2004). Al-Tasamuh al-Islami bayna al-Haqiqat wa al-'Iftari. In. Mahmud Hamdi Zaqzuq. Al-Tasamuh fi al-Hadharah alIslamiyyah, p 229-234. Cairo: n. p.

Sinar Harian News. 14 February 2015. (http://www.sinarharian.com.my/hiburan/ rusia-kekalkan-larangan-berhijab/). [16 February 2015].

Cohen, L. Manion, L. Morrison, K. (2000). Research Methods in Education. Firth edition. London: Routledge Palmer.

Creswell, J.W. (1994). Research design: qualitative and quantitative approaches. Thousand Oaks: Sange.

Fink, A. (1995). How to sample in survey. London: Sage Publications.

Frechtling, S. \& Westat. (1997). User-Friendly Handbook for Mixed Method Evaluations. Arlington, VA: National Science Foundation.

Ibrahim, S. (2005). History of the Malay Kingdom. Bangi: Penerbit Universiti Kebangsaan Malaysia.

Jaffary Awang et. al. (2007). Pengetahuan Agama dan Interaksi Sosial di Kalangan Mahasiswa Universiti Sains Malaysia Serta Kesan Terhadap Tahap Toleransi Beragama. In. Islam dan Isu-Isu Kontemporer: Respon Islam Terhadap Problematika Global \& Kearifan Lokal. Hamadi Husain et. al. p: 179-188. Bangi: Jabatan Usuluddin \& Falsafah, FPI, Universiti Kebangsaan Malaysia.

Jidmoud, S. (1988). Ethnic Groups: Muslim Thais. Bangkok: Sanga Suchira Amphone.

Krejcie, R. V. \& Morgan, D. W. (1970). Determining size for research activities. Education and Psychological Measurement. 30: 607-610.

Malcolm, D. E. (2004). Historical Analysis of Freedom or Belief as a Tehnique of Resolving Religious Conflict. In. Facilitating Freedom of Religion or Beliefe: A Deskbook. Tore L. W. et. al. Netherland: Martinus Nijhoff Publicher.

Mohd Majid Konting. (1994). Kaedah penyelidikan pendidikan. Kuala Limpur: Dewan Bahasa dan Pustaka. 
Najeemah Mohd Yusof. (2005). Pola Interaksi Sosial dalam Kalangan Murid Pelbagai Etnik di Sekolah Menengah Kebangsaan Sekitar Sungai Petani, Kedah. Tesis Doktor Falsafah Universiti Utara Malaysia. hlm 9.

Nik Anuar, N. M. (2006). History of the Struggle Patani Malay 1785-1954. Bangi: Universiti Kebangsaan Malaysia.

Panjor. R. (2012). Demonstration in Yala. Prince of Songkhla University Pattani Campus: Deep South Watch.

Pissuwan, S. (1982). Integration of Muslim Malays in Thailand during Rattana Kosin. Bangkok: Institusi Thai Studies, Thammasat University.

Robert, A. D. 1971. Polyarchy: Participation and Opposition. New Haven: Yale University Press.

Saleh, R. (2001). Interaction between Muslim and Buddhist in Pattani, Yala and Narathiwat. Bangkok: Office of Research Funds.

Sulaiman Ibrahim. (2003). Kepercayaan Agama dan Kepentingannya Dalam Masyarakat Majmuk. Dlm. Jaffary Awang, Mohd Nasir Omar, Muda @ Ismail Ab. Rahman. Agama dan Perpaduan Kaum di Malaysia, p: 150-167. Kuala Lumpur: Marindo Printers Sdn. Bhd.

Tonsungnern, S. (2010). People's Opinion on Right and Freedom: A Case Study of Victory Manument Sub-District, Bang Khen District, Bangkok. Thammasad University: Jurnal.

Wan Kadir Che Man. (1998). Islam in Patani Current. In. Fariz, M. Z. Zulkarnain, M. \& Samsu Adabi, M. Muslim Minority in Thailand. Bangi: Penerbit L Minda.

Wiseman, D. C. (1999). Research strategies for education. Belmont: Wadsworth Publishing Company. 